\title{
EDUCATIONAL MANAGEMENT AND THE STRESS OF THE TEACHERS
}

\author{
By \\ Mr. Zafarullah Sahito \\ Ms. Sultana Solangi"• \\ Mr. Muhammad Kamran Abbasi ${ }^{\text {0.0 }}$
}

\section{Abstract}

Educational Management consists of organized group of officials to make, manage and implement the rules, regulations and policies in the educational organizational structure in order to enhance the teaching and learning process. Teaching is considered as a respectable, important and prophetic profession, but in Pakistan its theoretical and practical position is unsatisfactory. Due to some internal and external factors of the management, the stress among teachers is increasing day by day which affects the efficiency and the working progress of the teachers negatively.

This research study is designed to collect the data from the teachers, Headmasters, District Education Officers (DEOs), Executive District Education Officer EDEO, of the District Hyderabad through Openended questionnaire and interviews in order to reach the conclusions about the Stress of the teachers. In this connection, 100 High School teachers, 20 Headmasters, DEOs and EDO were constituted as sample of the study. Simple random sampling technique was used to select schools as well as the respondents.

This study highlights the various stress factors and mitigation measures which will help in the enhancement of the policy making and implementation and the working efficiency and capability of the educational administration and management at the district level. It also suggests the methods and techniques to reduce the stress of the teachers for better performance.

\footnotetext{
- The writer is working in Department of Educational Management and Supervision, Faculty of Education, University of Sindh. Elsa Kazi Campus, Hydeabad.

- The writer is working as Inncharge and Assistant Professor, Department of Science and Technical Education, Faculty of Education, University of Sindh, Elsa kazi Campus, Hydeabad.

.. The writer is working as Lecturer, Department of Distance, Computer and Continuing Education, Faculty of Education, University of Sindh. Elsa kazi campus, Hydeabad.
} 


\section{Introduction}

The slogan of the modern time among the public and private agencies, policy makers, curriculum developers, educationalists, administrators, teachers, students and their parents in Pakistan are the quality education or the quality in education. Above all, concern officials tried to fulfil their duties and responsibilities very well according to their capacities and energies. But, there might be the improper planning which was not supposed to be made and implemented due to different reasons in the system of education in our country; or there might be the proper relationship, connection, cooperation, coordination, assessment and evaluation was not done systematically and correctly. The Bureau of Curriculum and Extension Wing, District Education Administration and Management, Board of Intermediate and Secondary Education, and the affiliated High Schools are interrelated to each other. They work together for the enhancement of the quality of education in their particular areas. But, no one is taking any particular steps for the quality and enhancement of the skills and expertise of the teachers at large. Political interference and influence, corruption, improper implementation of the policies, rules, regulation, postings of the teachers, head masters, Assistant District Education Officers, District Education Officers and Executive District Education Officers as well as the illegal demands of the Unions of Teachers and the unsuitable selection procedure of the teachers may be the main causes which create hurdles and problems in the smooth running of the quality education in Pakistan. If above all factors are true, then there is a great possibility of increase of the tension and the stress of the teachers and heads of schools and officers. The teachers play vital role in the whole system of education they make good and strong social relations among the students, parents, administration and the society. They also uplift the students from all point of views through the teachings of life, humanity, wisdom and power, social and emotional development and the fulfilment of the Huqooq-ul Allah and Huqooq-ul-lbad and for the betterment of the people here in the world as well as life hereafter.

History highlights the importance of the teacher not only in the modern times but also in the past. All nations of the world believed and also trusted in great sacrifice, hard work, intelligence, sense of duty, trustworthy, honesty, loyalty, sincerity, leadership, punctuality, etc of their teachers. That's why they gave an honorable position to their teachers in their country as well as in their hearts. In developed countries of the world teachers are considered as the pillars and the developers of the nation. But, in our Pakistan, the teachers and the teachings are passing from the worst and the difficult period of the time. Even they have lost their proper, actual and important position due to different 
factors and levels of stress among teachers, supervisors, headmasters, officers, etc.

Stress is a word derived from the Latin word stringere, meaning to draw tight, and was used in the eighteenth century to describe hardship and affliction, (Hinkle, 1973). Stress is a condition which creates a tension or psychological pressure upon the mind of the person/teacher. As we know very well that the tension or pressure on mind creates different hurdles, difficulties and problems in daily life, and these problems do not allow the condition of mind to work freely and independently with proper attention. Stress is also defined as an organism's total response to environmental demands or pressures, but the stress in human beings is primarily an external response that can be measured by changes in daily routines, physical functions and through the interpretation of the reactions. (Rebecca J. Frey).

\section{Stress in the view of the different writers /Researchers.}

Occupational stress has been described as the experience of negative feelings, such as frustration, worry and anxiety, perceived to arise from work related factors (Kyriacou, 200I). There exists a substantial body of literature describing teaching as a stressful occupation and suggesting that the teacher's stress appears to be an increasing problem (Antoniou, Polychroni and Vlachakis, 2006; Chaplain, 1995; Guthrie, 2006; Kyriacou, 200I; Laughlin, 1984; Manthei and Gilmore, 1996; Munt, 2004; Punch and Tuetteman, 1996). While the literature concerning occupational stress in school settings has, naturally enough, focused on the teachers, there has been too little investigation of this phenomenon in non-teaching staff members.

Occupational stress has been associated with burnout, which is considered as a product of long term exposure to stress (Burke and Greenglass, 1994; Mearns and Cain, 2003). It has also been strongly associated with temporary and chronic illnesses, such as headache, hypertension, reduced immune response, stomach complaints, ulcers, depression and stroke (Ashcraft, 1992; Burke and Greenglass, 1994; Guthrie, 2006; Kahn and Byosiere, 1992; Kyriacou, 200I; Kyriacou and Sutcliffe, 1977). Occupational stress has been linked to decreased job satisfaction and job commitment, absenteeism (some of it probably due to illness), turnover and reduced performance (De Nobile and McCormick, 2007; Jepson and Forrest, 2006; Kyriacou, 200I; Chinsky, 2000; Spector, 2000).

Dr. Liza Nagel says: "What we see from research is that students sense teacher stress and react to it. Sometimes, the reaction is exactly what the 
teacher does not need: acting out." Hinkle (1973) records that 'stress denoted 'force, pressure, strain, or strong effort', referring primarily to an individual, or to the individual's organs or mental powers'. Richard S. Lazarus (1993) suggests,' An individual's stress reaction 'depends on how the person interprets or appraises (consciously or unconsciously) the significance of a harmful, threatening, or challenging event.' Hans Selye (1956) says: 'Mental tensions, frustrations, insecurity, aimlessness are among the most damaging stressors, and psychosomatic studies have shown how often they cause migraine headache, peptic ulcers, heart attacks, hypertension, mental disease, suicide, or just hopeless unhappiness'. Montgomery and Evans (1987) says: "Stress is the application of some force and pressure." Freudenberger says: "Those in the helping profession of medicines, police, and teaching suffer high level of stress from constant pressures which are emotionally taxing and physically exhausting." Quick and Quick (1979) made a careful study of Stress in organizational setting,' the major sources of stress in organizations (organizational stressors) involve role factors, job factors, physical factors, and interpersonal factors'.

Only those nations are known as the developed nations whose teachers are free from the stress because teachers are the makers and the developers of the nations. The brilliant, trained, active, cooperative, and intelligent teachers are the symbol of success but the stress free teachers are the symbol of the development and a source of pride for the nation and the coming generations. It is a Job Stress which creates the critical conditions for the teachers and also disturbs them throughout the service and especially during working hours. Teacher is a leader who leads the whole group of students and tries to infuse the different skills and flourish the efficiencies of the students for the development of their selves and the nation.

Following are the stressors/descriptors of the study:

- Financial Factors.

- Posting and Transportation.

- Un-availability of Facilities in Schools.

- Work-Load.

- Autocratic Supervision at Schools.

- Autocratic Supervision at District Head Office.

- Political Pressures.

- Parental Pressures.

- $\quad$ Pressures of Domestic Life. 


\section{Statement of the Problem}

In $21^{\text {st }}$ century stress is considered as the cancer of the mind which does not allow the teacher to think even about his duties and responsibilities. Teacher faces many physical as well as psychological problems during working hours due to job stress. This research specially focuses on the causes of the job stress and its impact on the performance of the teachers.

Educational Management consists on organized group of officials to make, manage and implement the rules, regulations and policies in the educational organizational structure in order to enhance the teaching and learning process. Teaching is considered as the respectable, important and prophetic profession, but in Pakistan its theoretical and practical position is unsatisfactory. Due to some internal and external factors of management, the stress among teachers is increasing day by day which affects the efficiency and the working progress of the teachers negatively. Because, during stress the capacity of work, activeness, energies, behavior, senses, ideas, thoughts, teaching style / methods, etc. of the teacher are affected and the required result will not be achieved.

Through this study the factors of the stress of the teachers are found and the conclusions were made. In this connection suggestions are also given for the improvement of the policies and the modification of the behaviour of the officers and seniors with their junior staff and colleagues. It is also suggested that the teaching learning can be improved through the cooperation, coordination, the healthy teaching learning environment and the direct and indirect participation of the teachers, headmasters, supervisors, administrators/ officers, evaluators, students and their parents.

\section{Objectives}

I. To understand the nature of the Stress.

2. To find out the causes of the Stress.

3. To find out the impact of the stress on work of the teachers.

\section{Delimitation of the Study}

The study is delimited to:

- The Government Boys High Schools of Hyderabad city, Latifabad and Qasimabad talukas.

- $\quad$ Only male high school teachers, who teach in class IX and X.

- Head Masters of Government Boys High Schools of Hyderabad city, Latifabad and Qasimabad talukas (Total GBHS= 40).

- $\quad$ Concerned DEOs and EDO of Hyderabad district. 


\section{Population}

All the teachers, headmasters of 40 (Forty) Government Boys High Schools and the concerned officers of district education office of the Hyderabad district are constituted as the population of the study.

\section{Sample}

- $\quad 100$ HSTs, 20 Headmasters, DEOs, and EDO were constituted as sample of the study.

- $\quad$ Simple random sampling technique was used to select 20 (Twenty) Government High Schools (50\% sample of total number of GBHS from the population).

- HSTs male (high school teachers), who teach in class IX and X.

\section{Tools}

- $\quad$ Closed and Open- Ended Questionnaire.
Interview

\section{Research Methodology and Procedure}

The Descriptive survey research design was used to find out the factors of cause of the stress on the teachers and its impact on the working condition of the teachers. Before the construction of the questionnaire and interview, 10 teachers were interviewed in order to collect the proper and correct descriptors for the study. After finding of the descriptors the closed and Openended questionnaire was designed and interviews were also conducted. Questionnaire consists on section "A" and "B" were filled in by the HSTs who teach in class $I X$ and $X$. Interviews were conducted from the EDEO, DEOs, ADEOs and Head Masters of GBHS.

\section{Data Analysis and Interpretation}

\begin{tabular}{|llcc|}
\hline- & Y & YES & $100 \%$ \\
\hline- & U-D & UN-DECIEDED & $50 \%$ \\
\hline & N & NO & $00 \%$ \\
\hline
\end{tabular}

The interpretation and analysis of the collected data through questionnaire consists on appendix " $A$ " and " $B$ " is presented in the tables and graphs as follows: 


\section{Table - I}

\section{Financial Factors}

\begin{tabular}{|l|c|c|c|c|c|c|}
\hline \multicolumn{1}{|c|}{ FACTORS } & Y & PER: & U-D & PER: & N & PER: \\
\hline Insufficient monthly salary. & 98 & $98 \%$ & 02 & $02 \%$ & 00 & $00 \%$ \\
\hline Late payment of salary. & 87 & $87 \%$ & 08 & $08 \%$ & 05 & $05 \%$ \\
\hline No qualification increments. & 58 & $58 \%$ & 06 & $06 \%$ & 36 & $36 \%$ \\
\hline No promotions. & 91 & $91 \%$ & 00 & $00 \%$ & 09 & $09 \%$ \\
\hline
\end{tabular}

Table I shows the High Stress among the teachers, the average stress is $\mathbf{8 3 . 5}$ percentage.

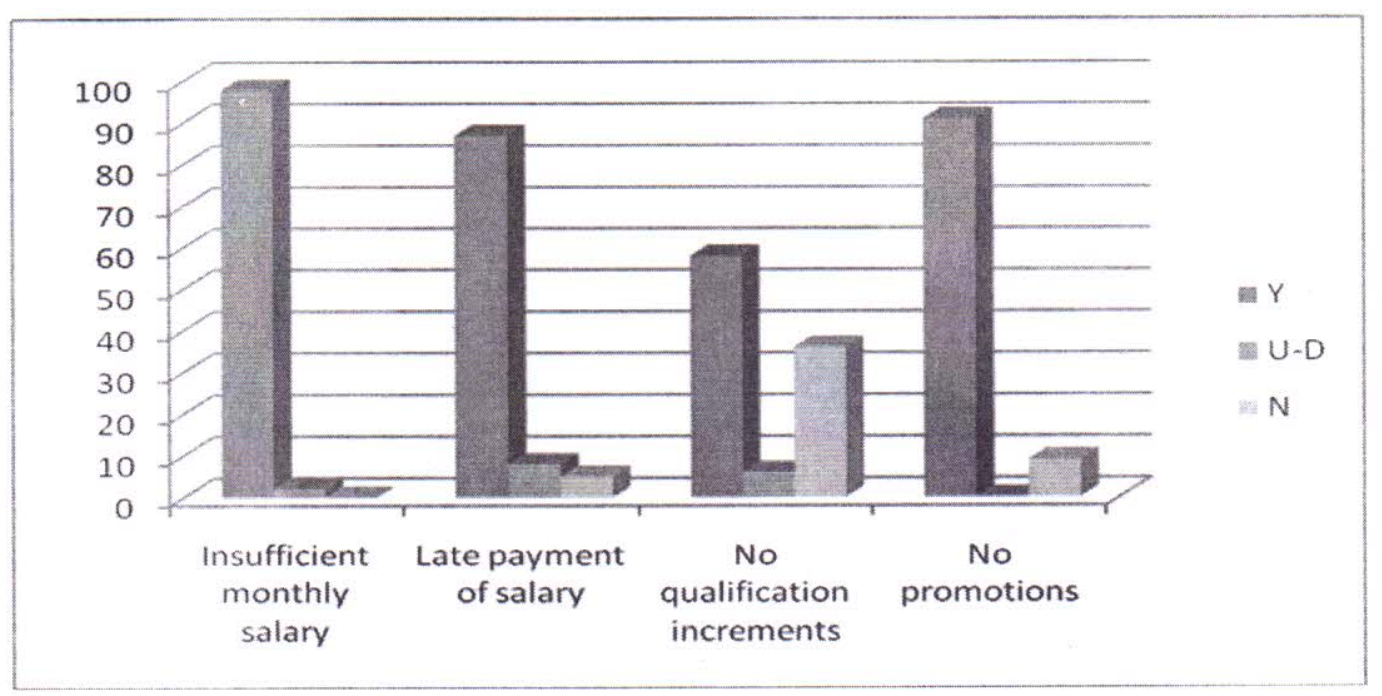

Table - 2

Posting and Transportation Factors

\begin{tabular}{|l|l|l|l|l|l|l|}
\hline FACTORS & Y & PER: & U-D & PER: & N & PER: \\
\hline Out station posting. & 83 & $83 \%$ & 11 & $11 \%$ & 06 & $6 \%$ \\
\hline Unavailability of transportation. & 71 & $71 \%$ & 21 & $21 \%$ & 08 & $8 \%$ \\
\hline Avail more than two/three vehicles to reach school. & 69 & $69 \%$ & 03 & $3 \%$ & 28 & $28 \%$ \\
\hline
\end{tabular}

Table 2 shows the High Stress among the teachers, the average stress is $\mathbf{7 4 . 3 3}$ percentage. 


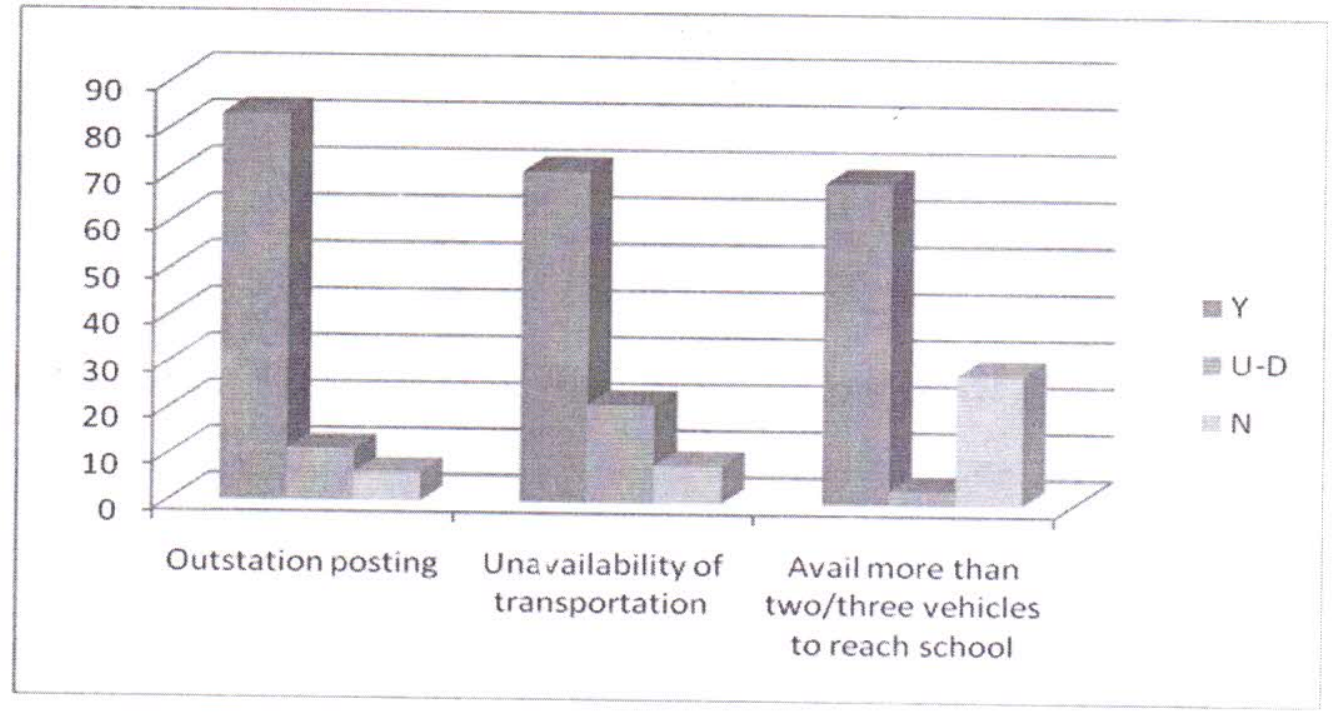

Table -3
Factors of Un-availability of Facilities
\begin{tabular}{|l|c|c|c|c|c|c|}
\hline \multicolumn{1}{|c|}{ FACTORS } & Y & PER: & U-D & PER: & N & PER: \\
\hline Unavailability of proper Library. & 65 & $65 \%$ & 00 & $00 \%$ & 35 & $35 \%$ \\
\hline Unavailability of suitable books. & 85 & $85 \%$ & 00 & $00 \%$ & 15 & $15 \%$ \\
\hline Unavailability of equipments in labs. & 70 & $70 \%$ & 10 & $10 \%$ & 20 & $20 \%$ \\
\hline Unavailability of suitable staff room. & 56 & $56 \%$ & 23 & $23 \%$ & 21 & $21 \%$ \\
\hline Unavailability of lockers in staff room. & 74 & $74 \%$ & 15 & $15 \%$ & 11 & $11 \%$ \\
\hline
\end{tabular}

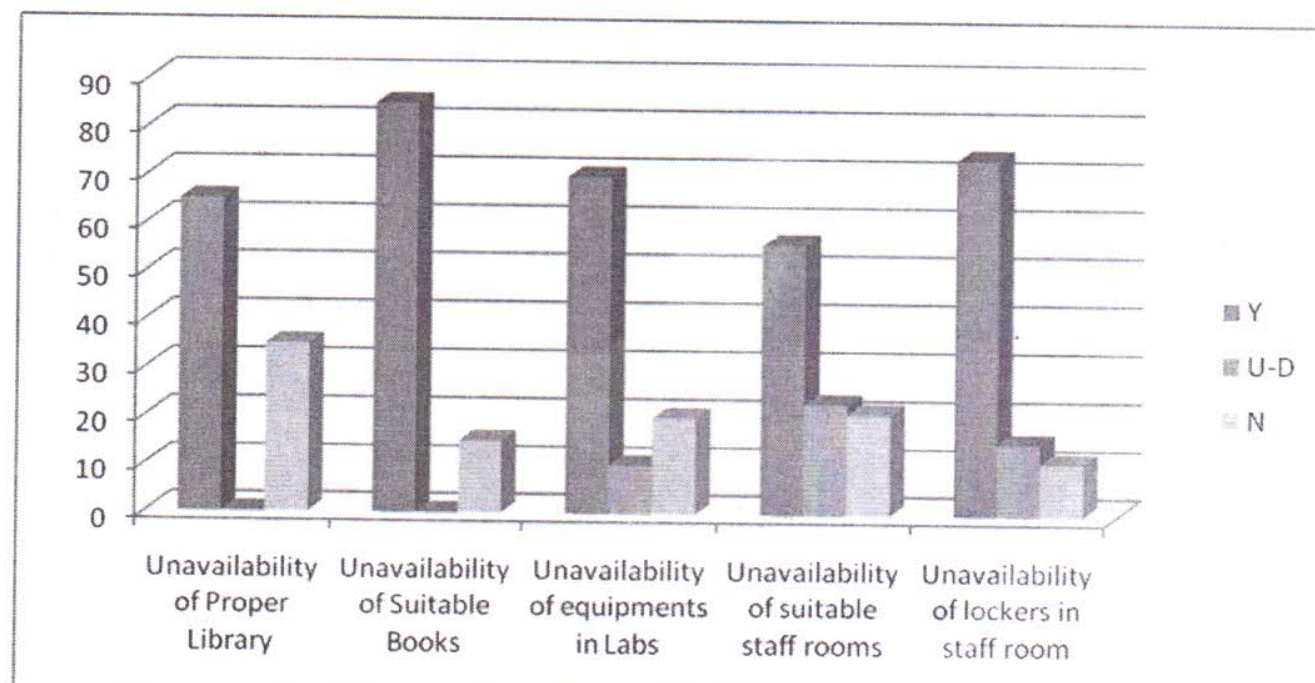

Table 3 shows the High Stress among the teachers, the total average stress is 70 percentage. 
Table -4

Workload Factors

\begin{tabular}{|l|c|c|c|c|c|c|}
\hline \multicolumn{1}{|c|}{ FACTORS } & Y & PER: & U-D & PER: & N & PER: \\
\hline Extra subjects (more than three/four). & 69 & $69 \%$ & 3 & $3 \%$ & 28 & $28 \%$ \\
\hline Irrelevant subjects to qualification. & 57 & $57 \%$ & 7 & $7 \%$ & 36 & $36 \%$ \\
\hline Worrying about completion of course. & 93 & $93 \%$ & 4 & $4 \%$ & 3 & $3 \%$ \\
\hline Non-availability of A.V. aids. & 67 & $67 \%$ & 19 & $19 \%$ & 14 & $14 \%$ \\
\hline Extra engagement of classes. & 70 & $70 \%$ & 17 & $17 \%$ & 13 & $13 \%$ \\
\hline Proper checking of copies. & 83 & $83 \%$ & 3 & $3 \%$ & 14 & $14 \%$ \\
\hline Examination duties in Board papers. & 87 & $87 \%$ & 6 & $6 \%$ & 7 & $7 \%$ \\
\hline
\end{tabular}

Table 4 shows the High Stress among the teachers, the average stress is 75.14 percentage.

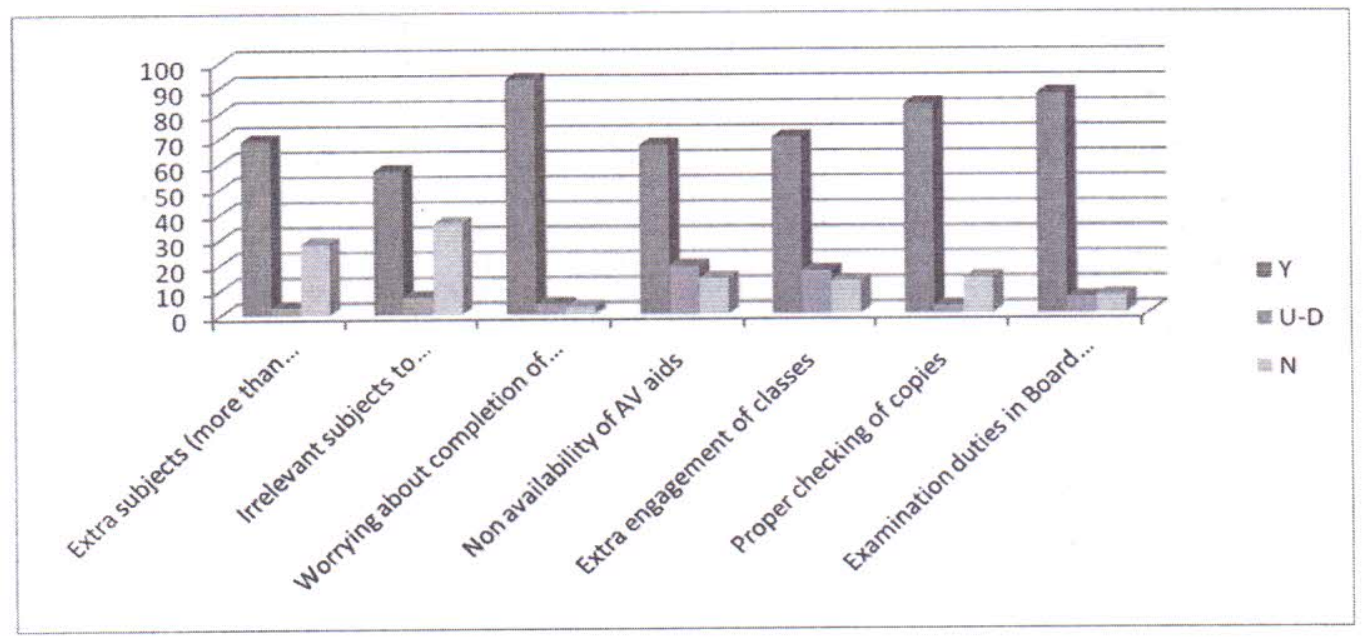

\section{Table - 5}

Factors of Autocratic Supervision in School

\begin{tabular}{|l|c|c|c|c|c|c|}
\hline \multicolumn{1}{|c|}{ FACTORS } & Y & PER: & U-D & PER: & N & PER: \\
\hline Strict behavior of the heads. & 97 & $97 \%$ & 00 & $00 \%$ & 3 & $3 \%$ \\
\hline Non-cooperative heads. & 78 & $78 \%$ & 14 & $14 \%$ & 8 & $8 \%$ \\
\hline Non-cooperative colleagues. & 99 & $99 \%$ & 00 & $00 \%$ & I & $1 \%$ \\
\hline Professional jealously. & 99 & $99 \%$ & 00 & $00 \%$ & $\mathrm{I}$ & $1 \%$ \\
\hline Leave taking problem. & 62 & $62 \%$ & 7 & $7 \%$ & 31 & $31 \%$ \\
\hline
\end{tabular}

Table 5 shows the High Stress among the teachers, the average stress is $\mathbf{8 7}$ percentage. 


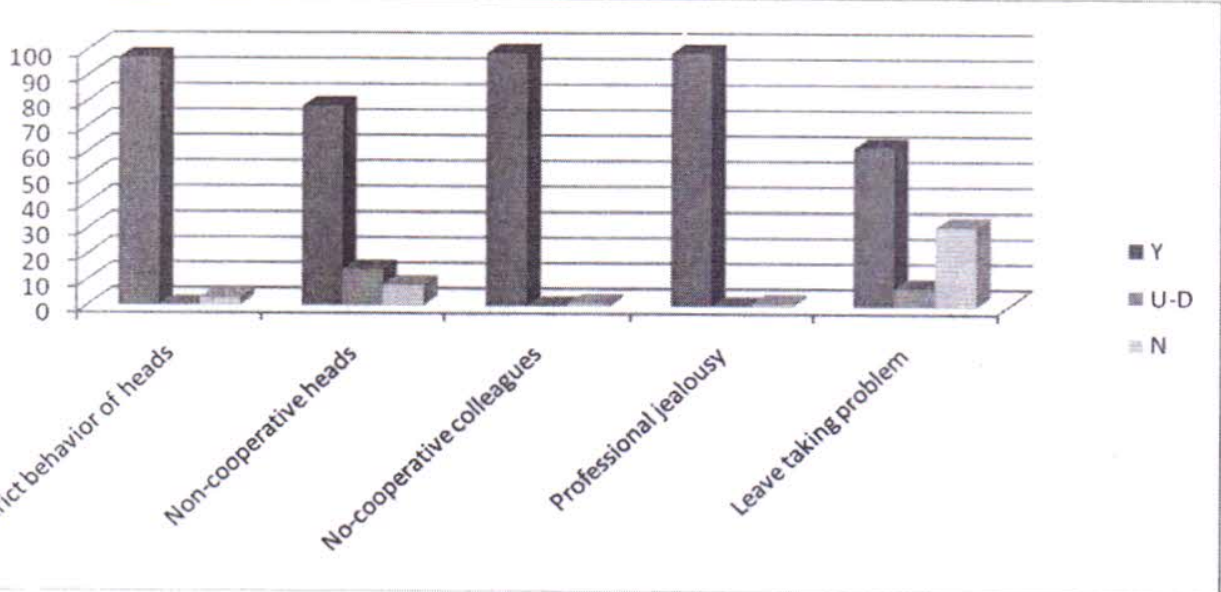

Table - 6

Factors of Autocratic Supervision at District Head Office

\begin{tabular}{|l|c|c|c|c|c|c|}
\hline \multicolumn{1}{|c|}{ FACTORS } & Y & PER: & U-D & PER: & N & PER: \\
\hline No response by the heads. & 81 & $81 \%$ & 3 & $3 \%$ & 16 & $16 \%$ \\
\hline Illegal pressure by the heads. & 67 & $67 \%$ & 14 & $14 \%$ & 19 & $19 \%$ \\
\hline Illegal demands by the administration. & 87 & $87 \%$ & 2 & $2 \%$ & 11 & $11 \%$ \\
\hline
\end{tabular}

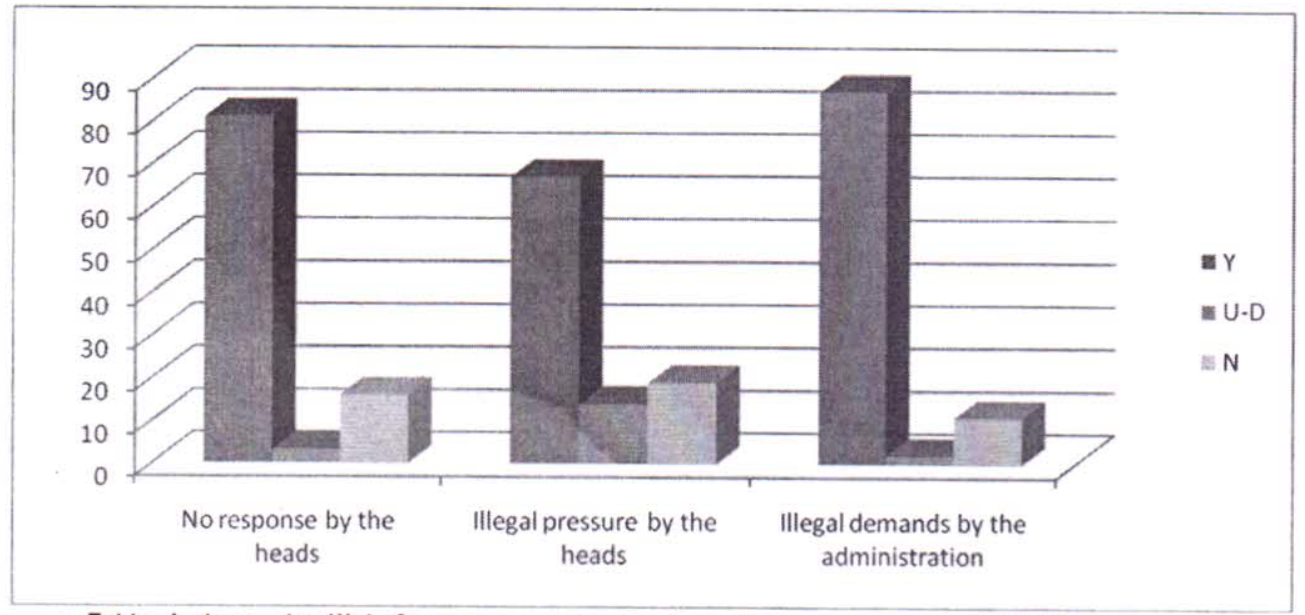

Table 6 shows the High Stress among the teachers, the average stress is 78.33 percentage.

Table -7

Political Factors

\begin{tabular}{|l|c|c|c|c|c|c|}
\hline \multicolumn{1}{|c|}{ FACTORS } & Y & PER: & U-D & PER: & N & PER: \\
\hline Illegal pressure by the Nazim. & 69 & $69 \%$ & 11 & $11 \%$ & 20 & $20 \%$ \\
\hline Illegal pressure by the political group / party. & 71 & $71 \%$ & 7 & $7 \%$ & 22 & $22 \%$ \\
\hline Illegal pressure by the Teachers Unions. & 73 & $73 \%$ & 12 & $12 \%$ & 15 & $15 \%$ \\
\hline
\end{tabular}




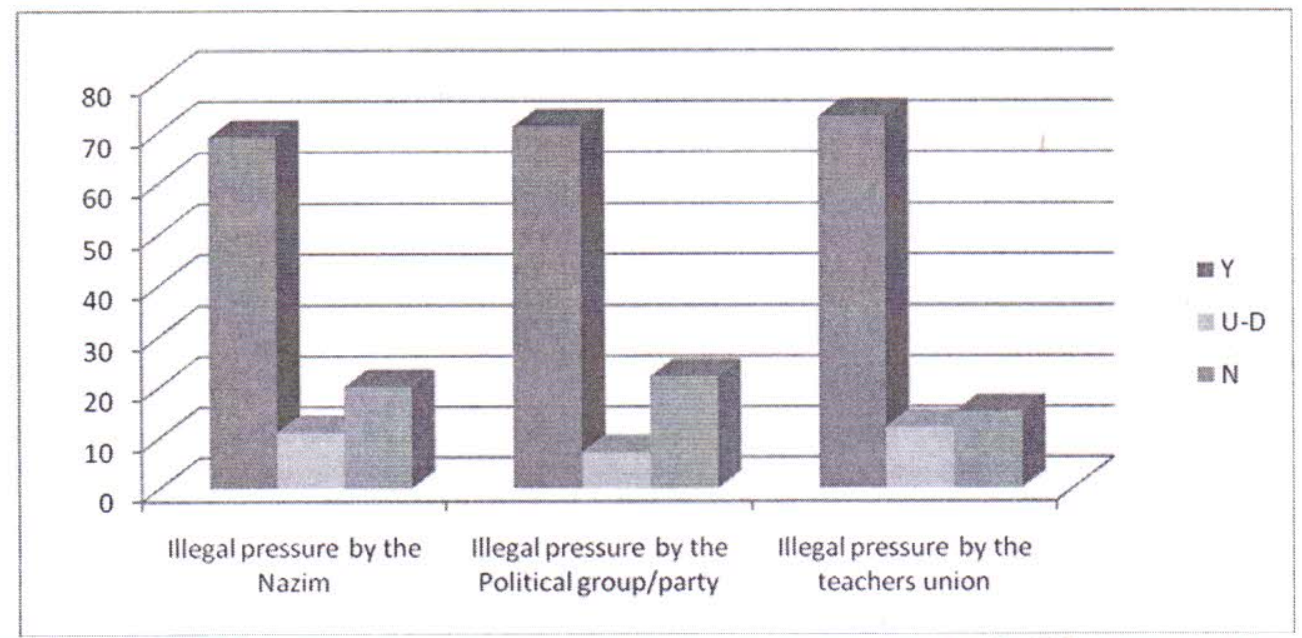

Table 7 shows the High Stress among the teachers, the average stress is 71 percentage.

Table - 8

Factors of Parental Pressures

\begin{tabular}{|l|c|c|c|c|c|c|}
\hline \multicolumn{1}{|c|}{ FACTORS } & Y & PER: & U-D & PER: & N & PER: \\
\hline Any complaint by parents. & 11 & $11 \%$ & 27 & $27 \%$ & 62 & $62 \%$ \\
\hline Any complaint by student regarding teaching. & 09 & $09 \%$ & 36 & $36 \%$ & 55 & $55 \%$ \\
\hline
\end{tabular}

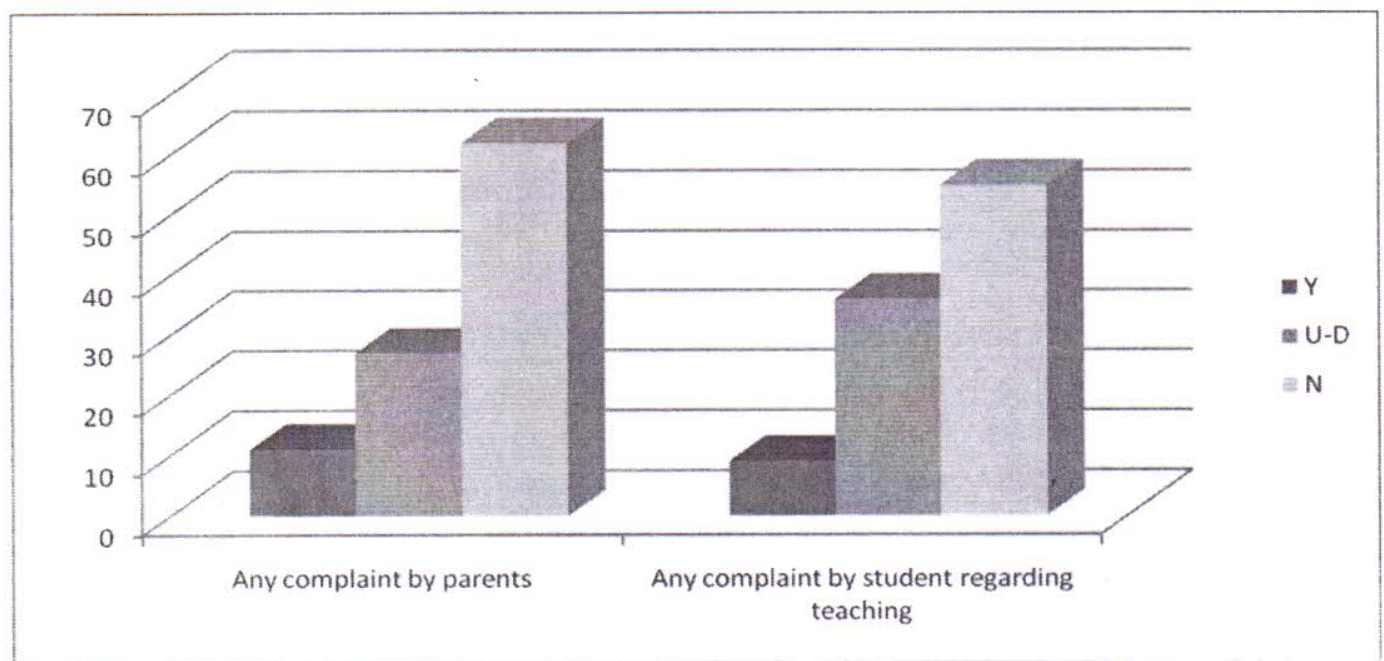

Table 8 shows the Low Stress among the teachers, the average stress is 10 percentage. 
Table - 9

Factors of Domestic Life

\begin{tabular}{|l|c|c|c|c|c|c|}
\hline \multicolumn{1}{|c|}{ FACTORS } & Y & PER: & U-D & PER: & N & PER: \\
\hline Any illness/disease of family members. & 80 & $80 \%$ & 4 & $4 \%$ & 16 & $16 \%$ \\
\hline Any children's care and education problem & 57 & $57 \%$ & 26 & $26 \%$ & 17 & $17 \%$ \\
\hline Any community pressure. & 73 & $73 \%$ & 19 & $19 \%$ & 8 & $8 \%$ \\
\hline Any expenditures pressure & 87 & $87 \%$ & 4 & $4 \%$ & 9 & $9 \%$ \\
\hline
\end{tabular}

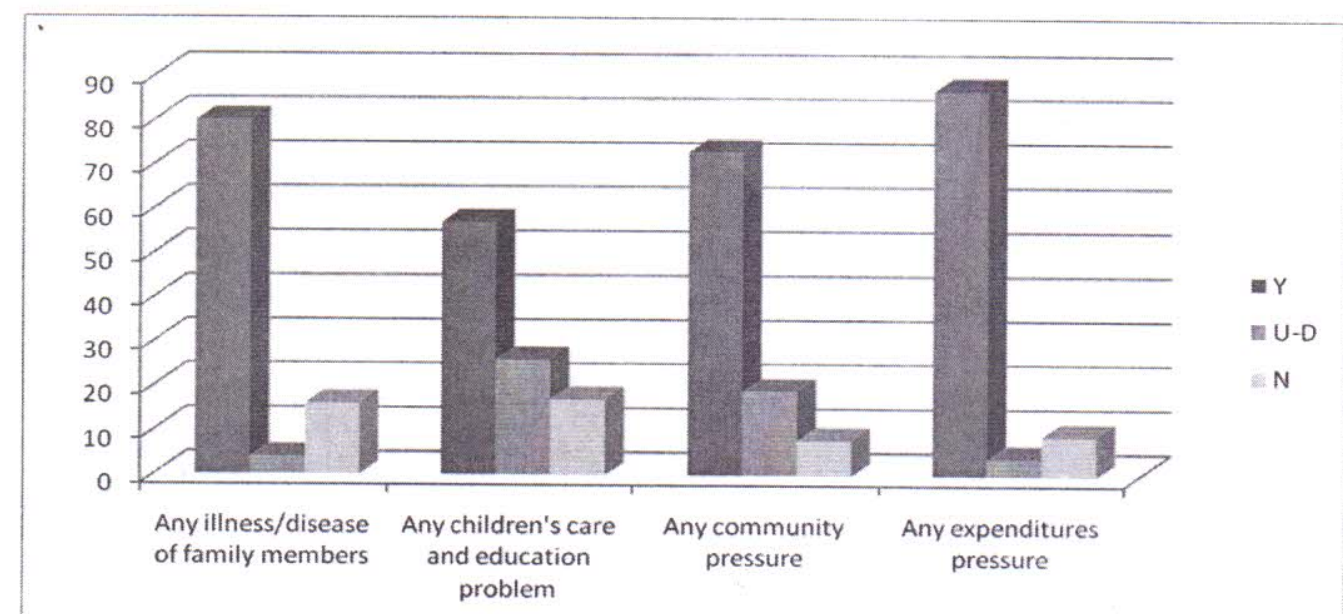

Table 9 shows the High Stress among the teachers, the average stress is $\mathbf{7 4 . 2 5}$ percentage.

Table - 10

Over all Factors and Stress

\begin{tabular}{|l|c|}
\hline Factors/Stressors & Average \\
\hline Financial factors & 83.5 \\
\hline Posting and transportation factors & 74.3 \\
\hline Factors of Un-availability of facilities & 70.0 \\
\hline Work load factors & 75.1 \\
\hline Factors of Autocratic Supervision in School & 87.0 \\
\hline Factors of Autocratic Supervision at District Head Office & 78.3 \\
\hline Political Factors & 71.0 \\
\hline Factors of Parental Pressures & 10.0 \\
\hline Factors of Domestic Life & 74.5 \\
\hline Overall Average Stress & $\mathbf{6 9 . 3}$ \\
\hline Standard Deviation & $\mathbf{2 2 . 9 2}$ \\
\hline
\end{tabular}

Table 10 shows the High Stress among the teachers due to Autocratic Supervision which is 87 (on the average) and the total average stress is 69.3 along with 22.92 standard deviation. 
The interpretation and analysis of the collected data through questionnaire " $B$ " is presented as follows:

Q: Do above Stress factors/stressors have any negative effects on
your performance/teaching learning process?

In the response of above question $89 \%$ teachers agreed that due to stress/pressure we do not feel well during school hours. Some times we take short leave and some times request to our friends and colleagues to engage our classes/periods. Our practice also effects negatively on teaching learning process and the performance of the students.

Interpretation and Analysis of the Interview Conducted from the EDEO, DEOS, ADEOS, and Headmasters. $(n=0 I+4+20=25)$.

Factors increase the stress of the teachers.

\section{Findings}

- $\quad$ Teachers face many financial problems and difficulties in their daily life due to expenses of their families and their selves.

- Non-availability of medical facilities depresses them and also increases their medical expenses.

- $\quad$ Out-Station posting and specially unavailability of easy transport are the main stressors.

- Unavailability of the facilities of suitable staff room, lockers. Library, books, computer, and internet in the majority of the schools.

- $\quad$ Extra Work-Load of periods and office is found on the competent and sincere teachers.

- Autocratic supervision creates the communication gapes between the heads and the sub-ordinates in School organization.

- Autocratic supervision at District Head Office increases the problems and difficulties and the intensity in stress which affect negatively on the working condition of the teachers.

- Political Pressures snatch the sincerity, loyalty and sense of duty from the majority of the teachers.

- Parental Pressures were not found at large due to extra control and the dominancy of the male teachers.

- $\quad$ Pressures of Domestic Life were found at large. 


\section{Conclusions}

On the basis of the collected data, the conclusion is drawn that Autocratic Supervision of the Head Masters and Educational Management/ Administration (means the officers) at district level is the major stressor which increases the stress of the teachers at large. Financial stressors, factors of domestic life, out-station posting and un-availability of transportation and political pressures are also the major stressors for the teachers.

Physical facilities like staff room, library, books, computers, internet, etc. also affect negatively on the working condition of the teachers during teaching learning process. Due to above mentioned facts the students of the Government High Schools suffer a lot and the schools also lose their standard day by day. That's why the government high schools are unable to do compete with the other public and private sector schools inside the province and the country.

Due to lack of the communication and professional jealousy, which are used negatively by some of the teachers in their day to day routines and due to unawareness to the rules of the democratic management, improper evaluation methods, political interference, improper selection method/criteria and the unauthentic knowledge of educational psychology, teaching methodologies, modern classroom management and audio visual aids the majority of the head teachers do know their duties and responsibilities properly which also causes the stress of the teachers.

\section{Suggestions}

- The monthly salary of the school teachers should be increased through up gradation like that of University teachers/lecturers.

- Increments of higher qualification should be given to the school teachers of all levels.

- Medical facilities should be provided to the school teachers according to their needs.

- Accommodation i.e. home or plot facility should be given to them. Motor cycle and computer loan facility should be given to school teachers for easy and convenient transportation.

- Provision of all possible and basic facilities to school teachers at their schools in order to accelerate the teaching learning process.

- To offer suitable trainings to the school teachers in order to improve their teaching methodology, assessment and evaluation techniques, educational psychology, classroom management, and proper usage of audio visual aids. 
- To offer suitable trainings to the heads of the schools as well as to the heads of Educational Management/Administration in order to deal and behave democratically with the sub-ordinates.

- The political interference and pressures should be avoided in order to save the Educational Institutions for their smooth running and the development of the country.

- The selection of the school teachers and officers in Education Department should be made on pure merit basis.

- The school teachers should be offered the courses of computer and internet for the enhancement of their knowledge.

- The heads of the schools should create the environment of competition among their teachers in order to increase and enhance their skills. 


\section{REFERENCES}

Antoniou, A.S., Polychroni, F. and Vlachakis, A.N. (2006). Gender and Age Differences in Occupational Stress and Professional Burnout between Primary and High-School Teachers in Greece. Journal of Managerial Psychology, 21 (7), 682-690.

Ashcraft, D.M. (1992). Health in the Workplace. In Kelley, K. (Ed.), Issues, Theory, and Research in Industrial / Organizational Psychology. (pp. 259-283). Amsterdam: Elsevier Science Publications B.V.

Burke, R.J. and Greenglass, E. (1994). A Longitudinal Study of Psychological Burnout in Teachers. Human Relations, 47 (3), I-I5.

Chaplain, R.P. (1995). Stress and Job Satisfaction: A Study of English Primary School Teachers. Educational Psychology, I5 (4), 473-489.

Cooper, C. (ed.) (1996). Handbook of Stress, Medicine and Health. CRC Press, Boca Raton, Florida.

De Nobile, J.J. and McCormick, J. (2007). Job Satisfaction and Occupational Stress in Catholic Primary Schools: Implications for School Leadership. Leading and Managing, I3 (I), 31-48.

Freudenberger, H.J. (1980). Burnout: the high cost of high achievement. N. Y: Doubleday.

Guthrie, R. (2006). Teachers and Stress. Australia and New Zealand Journal of Law and Education, II (I), 5-I8.

Hinkle, L. E. (1973). The concept of stress in the biological social sciences. Stress Medicine and Man I, 3I-48.

Jepson, E. and Forrest, S. (2006). Individual Contributory Factors in Teacher Stress: The Role of Achievement Striving and Occupational Commitment. British Journal of Educational Psychology, 76, 183-197.

Kahn, R.L. and Byosiere, (1992). Stress in Organizations. In M.D. Dunnette, and L. MHough, (Ed.s), Handbook of Industrial and Organizational Psychology (Volume 3). (pp. 57I-650). Palo Alto: Consulting Psychologists Press. 
Kyriacou, C. (2001). Teacher Stress: Directions for Future Research. Educational Review, 53 (I), 27-35.

Kyriacou, C. and Suttcliffe, J. (1977) Teacher Stress: A Review. Educational Review, 24 (4), 299-306.

Laughlin, A. (1984). Teacher Stress in an Australian Setting: The Role of Biographical Mediators. Educational Studies, 10 (I), 7-22.

Lazarus RS (1993). "From psychological stress to the emotions: a history of changing outlooks". Annual Review of Psychology 44: I-22.

Lazarus, R. E. (1976). Patterns of Adjustment. McGraw-Hill, New York.

Manthei, R. and Gilmore, A. (1996). Teacher Stress in Intermediate Schools. Educational Research, 38 (I), 3-19.

Mearns, J. and Cain, J.E. (2003). Relationships between Teachers' Occupational Stress and Their Burnout and Distress: Roles of Coping and Negative Mood Regulation Expectancies. Anxiety, Stress and Coping, 16 (I), 71-82.

Montgomery, B, and Evans, L. (1987). You and Stress: Melbourne: Nelson.

Munt, V. (2004). The Awful Truth: A Microhistory of Teacher Stress at Westwood High. British Journal of Sociology of Education, 25 (5), 578-59I.

Muchinsky, P.M. (2000). Psychology Applied to Work (6th ed.). Belmont: Wadsworth.

Petersen, C., Maier, S. F., Seligman, M.E.P. (1995). Learned Helplessness: A Theory for the Age of Personal Control. New York: Oxford University Press. ISBN 0-19-504467-3

Punch, K.F. and Tuetteman, E. (1996). Reducing Teacher Stress: The Effects of Support in the Work Environment. Research in Education, 56, 63-72.

Quick, J.C. and Quick, J.D. (1979). "Reducing Stress through preventive management”. Human Resource Management. 18 (3), 15-22.

Selye, Hans, MD. The Stress of Life. New York, Toronto, and London: McGrawHill Book Company, 1956.

Spector, P.E. (2000). Industrial and Organizational Psychology: Research and Practice (2nd ed.). New York: John Wiley and Sons. 